\title{
SEJARAH ISLAM DI KOTA BINTUHAN KECAMATAN KAUR SELATAN KABUPATEN KAUR
}

\author{
Bobi Syahri Adha, Maryam dan Japarudin \\ Jl. Bangka No.17, Belakang Pd., KUA Kota Bengkulu \\ bobisyahri@gmail.com
}

\begin{abstract}
Islamic History in Bintuhan, Kecamatan Kaur Selatan Kaur District. The issues examined in this thesis are: firts; What is the history of the entry of Islam in the City of Bintuhan in the District of South Kaur, Kaur Regency. Second; What are the traces of Islamic heritage in the City of Bintuhan, South Kaur District, Kaur Regency. This type of historical research uses snowball techniques in determining informants and collecting data using observation, interviews, documentation and recordings. The results of the study are as follows: firts; The history of the entry of Islam in the City of Bintuhan, South Kaur Subdistrict, Kaur Regency was brought by an Arab traveler, named Sayid Ahmad bin Ali bin Sheikh Abu Bakar who came from Hadramaut, Yemen in the mid 19th century AD in the Palembang Market area (the village of Cold Water) now known as the Masjid Village. Second; The traces of Islamic relics in the City of Bintuhan, South Kaur Subdistrict, Kaur Regency, namely in the form of Family Tomb Habib Ahmad bin Ali bin Sheikh Abu Bakr located in Jembatan Dua village, Puyang Pinang Tawar Tomb in Pengubaian village, Jamik Asyiriin Mosque in Kampung Masjid Air Cold, Bandar Old Mosque in Bandar Village / Sub-District, Documentation of Mu'awatul Her School Islamic Boarding School (MHS) obtained from H. Nuzuar Zahari Said in Air Dingin village (Kampung Masjid), Nahdlatul Ulama School (NU) at intersection 3 (three) Pasar Lama village and the last one is an old book / book in Arabic with the title Explanation of Various Sciences in the Qur'an belonging to Sayid Ahmad bin Ali bin Sheikh Abu Bakar.
\end{abstract}

Keywords: History, Islamic, Legacy, Bintuhan.

Abstrak: Sejarah Islam di Kota Bintuhan Kecamatan Kaur Selatan Kabupaten Kaur. Persoalan yang dikaji dalam skripsi ini, yaitu: pertama; Bagaimana sejarah masuknya Islam di Kota Bintuhan Kecamatan Kaur Selatan Kabupaten Kaur. Kedua; Apa saja jejak-jejak peninggalan Islam di Kota Bintuhan Kecamatan Kaur Selatan Kabupaten Kaur. Jenis penelitian historis (historical research) dengan menggunakan teknik bola salju (snowball) dalam menentukan informannya dan pengumpulan data menggunakan observasi, wawancara, dokumentasi dan rekaman. Hasil penelitian sebagai berikut: pertama; Sejarah masuknya Islam di Kota Bintuhan Kecamatan Kaur Selatan Kabupaten Kaur di bawa oleh seorang musafir Arab, bernama Sayid Ahmad bin Ali bin Syeikh Abu Bakar yang berasal dari Hadramaut, Yaman pada pertengahan abad ke-19 M di daerah Pasar Palembang (desa Air Dingin) yang sekarang dikenal dengan sebutan Kampung Masjid. Kedua; Adapun jejak-jejak peninggalan Islam di Kota Bintuhan Kecamatan Kaur Selatan Kabupaten Kaur, yakni berupa Makam Keluarga Habib Ahmad bin Ali bin Syeikh Abu Bakar terletak di desa Jembatan Dua, Makam Puyang Pinang Tawar di desa Pengubaian, Masjid Jamik Asy Syakiriin di Kampung Masjid desa Air Dingin, Masjid Tua Bandar di desa/Kelurahan Bandar, Dokumentasi Pondok Pesantren Mu'awatul Her School (MHS) yang di dapat dari H. Nuzuar Zahari Said di desa Air Dingin (Kampung Masjid), Sekolah Nahdlatul Ulama (NU) di simpang 3 (tiga) desa Pasar Lama dan yang terakhir buku lama/kitab berbahasa Arab dengan judul Penjelasan Berbagai Ilmu Dalam al-Qur'an milik Sayid Ahmad bin Ali bin Syeikh Abu Bakar.

Kata Kunci: Sejarah, Islam, Peninggalan, Bintuhan.

\section{Pendahuluan}

Pada kegiatan observasi awal, peneliti melihat sejumlah makam Islam yang diduga sebagai tokoh penyebar Islam di Bintuhan tersebut yakni, makam keluarga Habib Ahmad bin Ali bin Syeikh Abu Bakar. Makam ini terdiri dari seorang yang bernama Sayid Ahmad bin Ali bin Syeikh Abu Bakar beserta istrinya, Aliyah dan satu lagi bernama Sayid Abdullah bin 
Ahmad bin Syeikh Abu Bakar. Selain daripada itu, ada sebuah makam yang diberi nama makam Poyang Pinang Tawar terletak di desa Pengubaian Kecamatan Kaur Selatan. Menurut juru kunci makam tersebut, yakni Suardi bin Thahar dalam bukunya Zubir yang berjudul Peninggalan Sejarah dan Potensi Wisata Kabupaten Kaur Propinsi Bengkulu menjelaskan bahwa makam ini adalah makam Aminullah yang berasal dari Jawa sekitar abad ke-16 $\mathrm{M}$ datang ke Bintuhan. Kemudian selanjutnya, selain makam Islam terdapat dua buah masjid tua di sekitar Bintuhan ini. Diantaranya masjid Jamik Asy Syakiriin Bintuhan yang berdiri pada tahun 1832 dan masjid Tua Bandar yang berdiri pada tahun 1920-an oleh Haji Fikir Daud. ${ }^{1}$

Sebelumnya pada abad ke-17 M telah ada tanda-tanda berdirinya sebuah pondok pesantren yang di kenal dengan "Langgar Tarbiyah" oleh Syeikh Radhi yang terkenal dengan nama Syeikh Embacang Batu berfungsi sebagai tempat olah Rukhsyah bersama-sama muridnya, termasuk diantaranya pangeran Sebrani Puyang Kaur. ${ }^{2}$ Menurut Sidarmin Tetap, Langgar Tarbiyah ini baru eksis pada awal-awal kemerdekaan Republik Indonesia, yaitu sekitar tahun 1970-an.

Pada masa pemerintahan Kolonial Inggris, daerah Bengkulu di bagian Selatan termasuk Kaur (Bintuhan), sudah dikenal sebagai pusat pemasaran dagang $\mathrm{EIC}^{3}$ terhadap komoditi ladanya. Sehingga dalam perjanjiannya EIC akan memberikan perlindungan dan bantuan tentara terhadap ancaman-ancaman dari luar. 4

Menurut Marsden, lada Kaur atau lada Lampung adalah jenis lada dengan kualitas tinggi. Hal ini disebabkan karena buah dan daunnya yang besar, pertumbuhannya lebih lambat kemudian berdaya tahan lebih lama apabila dibandingkan dengan jenis lada Manna. ${ }^{5}$

Pada akhir abad ke-17 M kerajaan Banten mulai mengalami kemunduran karena Pelabuhan Sunda Kelapa yang sudah dikuasai oleh VOC pada tahun 1684. Untuk mempertahankan eksistensinya, penguasa Kerajaan Banten mencari daerah taklukan baru di pesisir Sumatera terutama yang dapat dijadikan sebagai pelabuhan pengganti Sunda Kelapa. Maka pada tahun 1693 Pangeran Santa bergelar Senehak utusan dari Banten tiba di Bintuhan. Ia merasa bahwa daerah tersebut dinilai sangat cocok dan strategis untuk dijadikan sebagai bandar dagang. Sehingga pada akhirnya Pangeran Santa mulai menguasai daerah-daerah disekitar Bintuhan lalu menyusun tata pemerintahan dan pembangunan pelabuhan yang nantinya akan berkembang menjadi salah satu pelabuhan dagang yang cukup diperhitungkan di pantai Barat Sumatra. ${ }^{6}$

Secara budaya daerah Bintuhan telah mendapat pengaruh yang cukup intensif dari pergerakan manusia. Mobilitas penduduk sekitar ketika menuju ibukota kapubaten telah berlangsung jauh sebelum kabupaten ini terbentuk, sehingga terbentuklah komunitas masyarakat baru dari hasil interaksi antarsuku bangsa yang datang ke daerah tersebut. Tiga suku bangsa utama seperti suku bangsa Minangkabau, telah datang pada saat program perluasan wilayah kekuasaan kerajaan Pagaruyung pada abad ke-18 $\mathrm{M}$ hingga ke Bintuhan, migrasi penduduk Pasemah dari Pagaralam sekitar awal abad ke-19 M dan suku Buai Harung dari Lampung yang lebih dahulu datang mendiami wilayah ini. ${ }^{7}$

Berdasarkan uraikan diatas, penulis merasa tertarik untuk melakukan penelitian lebih lanjut tentang proses Islamisasi di Kota Bintuhan tersebut. Mengapa tidak? Apabila dilihat dari sejarahnya, Kota Bintuhan adalah satusatunya Kota Bandar/pelabuhan yang terletak di bagian Selatan daerah Bengkulu dan keberadaannya juga patut diperhitungkan di pantai Barat Sumatra ini. Selanjutnya Kota Bintuhan (Kaur) 
merupakan jalur yang menjadi penghubung kerjasama antara Kerajaan Banten dengan Kerajaan Selebar di Bengkulu dalam bidang ekonomi dan politik. Kemudian yang terpenting adalah Kota Bintuhan merupakan penghasil komoditi lada berkualitas tinggi di Pulau Sumatra ini, sehingga tidak heran jika Bintuhan banyak dikunjungi oleh para pedagang lokal maupun asing untuk melakukan bertransaksi.

\section{Pembahasan}

\section{Sejarah Masuknya Islam di Kota Bintuhan Kecamatan Kaur Selatan Kabupaten Kaur}

a) Melalui Jalur Perdagangan

Sejarah masuknya Islam di Kota

Bintuhan merupakan bagian dalam proses Islamisasi di wilayah Kabupaten Kaur, Propinsi Bengkulu. Dahulu Kota Bintuhan ini dikenal sebagai kota bandar/pelabuhan terkenal pada saat itu, Sehingga banyak para pedagang dari luar berdatangan ke Kota Bintuhan seperti orang-orang Eropa (Belanda dan Inggris), orang Jepang, orang Cina bahkan orang Arab. Adapun hasil wawancara dengan informan Arpan Efendi mengenai sejarah masuknya Islam di Kota Bintuhan itu bahwa:

"Kalu kite liat sejarah itu, datangnye para musafir-musafir Arab, diantaranye Sayid Ahmad. Sayid Ahmad itu siapa?Musafir Arab berangkat dari Hadramaut, Yaman (hadir untuk maut; ya itu pembahasan dalam bahasa Arab).Diperkirakan pada 1816-1821 kehadiran awalnye."8

"Apabila kita lihat sejarah, bahwa datangnya para musafir Arab di antaranya Sayid Ahmad.Siapa itu Sayid Ahmad? Musafir Arab yang berasal dari Hadramaut, Yaman.Diperkirakan pada tahun 1816-1821 kehadiran awalnya."

Berdasarkan hasil wawancara dengan informan M. Shabri Abd Latief menjelaskan bahwa:

"Sayid Ahmad datang kesini man ku de salah tahun 18-an, anggaplah tahun 1832-an itulah. Daerah pe'tame yang nye datangi disini, daerah Pasar Palembang ni ae. Yelah Habib Luwi tian itu ketu'unannye itu. Yang ninggalnye di Pelimbang tu."

"Sayid Ahmad datang ke Bintuhan ini sekitar tahun 1832. Daerah pertama yang dia datangi ialah daerah Pasar Palembang (secara administratif masuk dalam desa Air Dingin).Sedangkan keturunannya ialah Habib Luwi. Yang meninggal di Kota Palembang, Sumatera Selatan."

Menurut pendapat lain menyebutkan bahwa Sayid Ahmad bin Ali bin Syeikh Abu Bakar berlayar bersamasama dengan kedua kawannya yang bernama Tuan Sayid Hadi dan Syeikh Muhammad Ali ${ }^{9}$ ini berasal dari Arab, kemudian berlayar menuju Palembang sampai pada akhirnya berlabuh di Kota Bintuhan. ${ }^{10}$ Ceritanya ketika Sayid Ahmad bin Ali bin Syeikh Abu Bakar ini berlayar dari Palembang menuju Kota Bintuhan, ternyata beliau membawa dua/tiga orang anaknya untuk ikut menemaninya berdagang. Salah satu diantara anaknya itu adalah Habib Alwi. ${ }^{11}$ Pada waktu rombongan Sayid Ahmad bin Ali bin Syeikh Abu Bakar tiba di Kota Bintuhan, daerah pertama yang mereka kunjungi adalah desa Air Dingin, tepatnya sekarang lebih dikenal dengan Kampung Masjid.12 Disinilah Sayid Ahmad bin Ali bin Syeikh Abu Bakar dan Syeikh Muhammad Ali menetap di Kota Bintuhan tersebut. Bedanya, Sayid Ahmad bin Ali bin Syeikh Abu Bakar sengaja mendirikan rumah disana untuk menetap dalam jangka waktu yang lama. Akan tetapi untuk Syeikh Muhammad Ali hanya menetap untuk sementara dengan menyewa/membeli rumah orang Cina disekitar Pasar Palembang itu dan kemudian beliau kembali ke Kota Palembang, Sumatra Selatan. Menurut informan M. Arsyad mengatakan bahwa:

"Sayid Ahmad dengan Syeikh Muhammad Ali ini tinggalnye di Kampung Masjid. Sayid Ahmad 'umahnye nyelah 
di'umah Marsikin bile ni. Sedangkan Syeikh Muhammad Ali ni 'umahnye pas dihadapan masjid Jamik kite ni."13

"Sayid Ahmad dengan Syeikh Muhammad Ali ini tinggalnya di Kampung Masjid. Sayid Ahmad rumahnya ialah berada dirumah Marsikin dulu. Sedangkan Syeikh Muhammad Ali ini rumahnya tepat berada di depan Masjid Jamik."

Syeikh Muhammad Ali datang ke Bintuhan bersama-sama dengan istri dan anak-anaknya dari Bengkulu. Kemudian mereka menetap di Bintuhan, tepatnya di depan Masjid Jamik Asy Syaakiriin. Sementara Tuan Sayid Hadi menetap di desa Binjai Kecamatan Tetap Kabupaten Kaur. ${ }^{14}$

b) Melalui Jalur Perkawinan

Berdasarkan data yang disampaikan oleh informan Arpan Efendi menjelaskan bahwa Islam di Bintuhan itu berasal dari tanah Arab langsung bukan dari Palembang, Padang maupun Banten. Sebagaimana pernyataannya di bawah ini:

"Maka begitu sampai di Pasar Lama dia menikah dengan seorang wanita situ. Berarti salah satu trik Sayid Ahmad bin Abu Bakar menikah dengan melalui perkawinan. Tapi nam taun nye menikah dengan orang Pasar Lama, idak ade anak, istrinye meninggal. Akhirnye merencanekan untuk kembali ke tanah Arab, Yaman tadi. Make dihadang ulih tue-tue disitu waktu itu. Dak usahlah balik Tuan Sayid, kalu yang kemarin istrimu yang ninggal yang pertama, dinikahkan lagi dengan wanita yang lain, yang masih saudara juga dengan istri yang pertama, namanye Aliyah.Nah dari Aliyah itulah lahir Habib, anak Sayid itukan Habib. Karne mereka masih keturunan para Nabi, keturunan Nabi Muhammad itu man kate kite Sayid."15

"Maka begitu sampai di desa Pasar Lama dia (Sayid Ahmad bin Ali bin Syeikh Abu Bakar) menikah dengan seorang wanita setempat. Berarti salah satu trik Sayid Ahmad bin Abu Bakar dalam mengenalkan Islam di sana ialah dengan melalui perkawinan. Tapi setelah
6 (enam) tahun dia menikah dengan orang desa Pasar Lama, tidak memiliki keturunan sehingga istrinya pun meninggal dunia.Akhirnya dia merencanakan untuk kembali ke tanah Arab, Yaman.Maka dihadang oleh para Tetua (orang-orang tua) disitu waktu itu. Sambil mengatakan bahwa tidak usahlah pulang Tuan Sayid, kalau kemarin istrimu yang pertama meninggal, dinikahkan lagi dengan seorang wanita yang lain yang masih merupakan saudari dari istrinya yang pertama yang bernama Aliyah. Dari Aliyah itulah lahir Habib.Maksudnya anak keturunan dari Sayid itu dinamakan Habib. Karena masih keturunan para Nabi, yakni keturunan Nabi Muhammad itu disebut dengan Sayid."

Pendapat tersebut di dukung olehinforman M. Napis Selamat yang mengatakan bahwa:

"Islam di Kabupaten Kaur, murninye orang Arab ade nikah disini, lah keturunan Sayid Ahmad. Nikahnye di Pasar Lame, yelah baknye Habib Luwi tu."16

"masuknya Islam di Kabupaten Kaur (Bintuhan) itu murni berasal dari Arab. Alasannya karena ada orang Arab menikah di Bintuhan, yaitu keturunan Sayid Ahmad.Menikahnya di desa Pasar Lama, bapak dari Habib Alwi."

Hal inilah yang menjadi dasar bahwa orang yang pertama kali mengenalkan agama Islam secara menyeluruh di daerah Bintuhan berasal dari tanah Arab, yaitu Sayid Ahmad bin Ali bin Syeikh Abu Bakar. Sehingga menurut informan Arpan Efendi menyampaikan bahwa:

"Walaupun sebelum Sayid Ahmad bin Abu Bakar tu sudah ada Islam, tapi tidak pesat. Kayak itu mereka masih sifatnye nafsinafsi atau sekelompok saje. Tapi setelah masuknye Sayid Ahmad, begitu Habib Alwi lah besak, udah mendunia, internasional Buyawan Habib Alwi itu."17

"Walaupun sebelum Sayid Ahmad bin Abu Bakar, Islam itu sudah ada tapi belum pesat. Pengenalan Islam itu masih 
bersifat nafsi-nafsi/sekelompok saja. Akan tetapi setelah masuknya Sayid Ahmad ke Bintuhan ini, begitu anaknya Sayid Ahmad, yakni Habib Alwi sudah tumbuh dewasa, akhirnya mendunia bahkan internasional Buyawan Habib Alwi tersebut."

Untuk mengetahui persoalan mengenai perkawinan dan anak keturunan Sayid Ahmad bin Ali bin Syeikh Abu Bakar ini dapat disimak melalui hasil wawancara dengan informan Rahima Thaib berikut ini:

"Tuan Sayid Ahmad ni jadi dengan Qiyame tu, yelah ade punye anak ape tige ape due anaknye itu, sekitar itu. Anak segale anaknye tu yang Sayid Husen, 'adu tu yang Sarifah Maryam, 'adu tu yang Sarifah Leha, 'adu tu Sayid Mahdi/Habib Mahdi, Habib Luwi. Habib Luwi kudai batu, Habib Luwi itu man aku de salah setuhenye anaknye dengan Qiyame tu. 'adu tu yang ini Sarifah Tulha tu jelah Ton panggilannye di Palembang."

"Tuan Sayid Ahmad ini nikah dengan Qiyama. Semua anaknya ada 6 (enam) orang, yakni Sayid/Habib Husein, Sarifah Maryam, Sarifah Leha, Sayid/Habib Mahdi, Habib Luwi (Alwi) dan Sarifah Tulha (Ton)."

Kemudian untuk anaknya Sayid Ahmad bin Ali bin Syeikh Abu Bakar yang bernama Habib Alwi ini, informan Rahima Thaib menambahkan dalam penjelasannya berikut ini:

"Bahwe Habib Luwi itu jadi dengan Cik Odo Zaina.Zaina itu anak $H$. Said, emaknye itu Si Jujah.Habib Luwi ini tinggal disini, ke'je e bedagang. Yelah tokonye dirumah Marsikin tu bile ni, nye tu toko pakaian. Setelah nye agak bangkrut mpai ni, nye Habib Luwi ni pindahlah ke Palembang buat Pabrik Tehel. Nah matilah nye di Palembang Cik Odo Zaina tian. Te'us tian ni pindah gale sepe'anakan, matilah tian itu di Palembang. Ketu'unannye tu ade, ketu'unan Cik Odo Zaina tian tu Apen, 'adu Fauzi. Fauzi tu lah ninggal, adu tu Ifah/Sarifah Qomariah, bini Suparwan Said, Sarifah 'Aisyah, namenye Acik-acik pai ni, 'adu tu Cuyah sikuk, Eni sikuk anaknye tu."18
"Bahwa Habib Luwi itu nikah dengan Zaina ${ }^{19}$ yang anaknya Bapak $\mathrm{H}$. Said, ibunya bernama Jujah.Habib Luwi ini tinggal di Bintuhan sini, bekerja sebagai pedagang.Tokonya terletak dirumah Bapak Marsikin dulu.Tokonya itu toko pakaian.Setelah agak bangkrut dulu, Habib Luwi ini pindah ke Kota Palembang untuk membuat Pabrik Tehel.Disanalah mereka meninggal dunia.Terus mereka pindah sekeluarga, akhirnya meninggallah mereka di Palembang. Keturunannya ada, keturunan mereka itu Apen, Fauzi, Sarifah Qomariah, Sarifah 'Aisyah (Acik nama panggilannya), Cuyah dan Eni."

c) Melalui Jalur Pendidikan

Pada waktu Sayid Ahmad bin Ali bin Syeikh Abu Bakar tiba di Kota Bintuhan untuk menyebarkan agama Islam kepada masyakarat pribumi, ternyata beliau mendirikan sebuah pondok pesantren yang dikenal dengan nama MHS (Mu'awanatul Her School) selain melalui jalur perdagangan dan perkawinan. Ketika Sayid Ahmad bin Ali bin Syeikh Abu Bakar itu wafat, maka pondok pesantren itu kemudian dikembangkan oleh anaknya, yaitu Habib Alwi. Penjelasan ini sebagaimana yang disampaikan oleh informan Arpan Efendi berikut:

"Habib Alwi punya gebrakan khusus untuk mengembangkan Ahlussunah wal Jamaah di Bintuhan ini, kemudian berdirinya pesantren hebat MHS namenye Mu'awanatul Her School di Gedung Sako itu." 20

Selanjutnya informan Arpan Efendi menambahkan penjelasan tentang pengembangan Islam di Kota Bintuhan ialah melalui musafir, perkawinan dan pendidikan. Setelah menikah mencoba untuk menerapkan budayanya orang Arab. Arab itu lebih senang kalau mengajar sesuatu itu melalui pondok/pemondokan. Maksudnya mereka itu benar-benar di dudukkan, 
duduknya tidak memakai kursi atau ngelepa'21. Untuk pusaka-pusaka merekapun masih ada, misalnya berupa kitab-kitab lama salah satunya yang berjudul al-Qur'anu wal 'ulúmul 'ashriyati (Penjelasan Berbagai Ilmu Dalam alQur'an) yang merupakan bukti peninggalan Islam di Kota Bintuhanmilik Sayid Ahmad bin Ali bin Syeikh Abu Bakar.

\section{Jejak-Jejak Peninggalan Islam di Kota Bintuhan}

Berdasarkan hasil observasi data dilapangan, peneliti menemukan bahwa ada beberapa jejak-jejak peninggalan Islam di Kota Bintuhan yakni berupa Makam Keluarga Habib Ahmad bin Ali bin Syeikh Abu Bakar, Makam Puyang Pinang Tawar, Masjid Jamik Asy Syakiriin, Masjid Tua Bandar, Pondok Pesantren Mu'awatul Her School (MHS), Sekolah Nahdlatul Ulama (NU) dan buku lama/kitab Sayid Ahmad bin Ali bin Syeikh Abu Bakar.

a) Makam Keluarga Habib Ahmad bin Ali bin Syeikh Abu Bakar

Makam ini merupakan makam tua yang diyakini masyarakat sebagai ulama/orang yang telah menyebar dan mengajarkan agama Islam di Kota Bintuhan. Dalam kegiatan observasi di lapangan, peneliti langsung mengunjungi lokasi Tempat Pemakaman Umum (TPU) yang berada tepat di depan masjid Darussalam di desa Jembatan Dua. Ketika tiba di lokasi pemakaman, terlihat dari luar gerbang/pintu masuk TPU ada sebuah cungkup besar di tengah-tengah TPU tersebut. Jarak antara pintu masuk TPU dengan cungkup yang ada di tengahtengah TPU tersebut kira-kira $10 \mathrm{M}$. Sebelum masuk ke dalam cungkup itu, ada sebuah tulisan "Bissmillaahirrahmaanirrahiim" dan "Innaalillahi wa innaailaihirooji'uun" dalam bahasa Arab dengan khat Naskhi serta tulisan "Makam Keluarga Habib Ahmad bin Ali bin Syeikh Abu Bakar" di samping kanan pintu masuk. Semua tulisan itu tintanya berwarna emas dan pada bagian pojok atas dan bawah sebelah kanan dan kiri tulisan tersebut ada hiasan seperti motif bunga yang berwarna emas juga dengan latar belakang media tulis memakai keramik berwarna hitam. Tulisan tersebut menghadap ke arah Selatan, sedangkan pintu masuk cungkup tersebut menghadap ke arah Timur. Ternyata tulisan itu sebagai petunjuk/tanda bahwa makam ini adalah makamnya keluarga Sayid Ahmad bin Ali bin Syeikh Abu Bakar.

Selanjutnya pada saat sampai di dalam cungkup itu, terlihat bahwa ada 3 (tiga) makam masing-masing bernama Sayid Ahmad bin Ali bin Syeikh Abu Bakar, wafat di Bintuhan pada tahun 1943 $M$ dan Aliyah istrinya Sayid Ahmad bin Ali bin Syeikh Abu Bakar wafat pada tahun 1919 M di Bintuhan. Kedua makam ini posisinya digabung dengan keramik berwarna putih sebagai pembatasnya. Kemudian yang satunya bernama Sayid Abdullah bin Ahmad bin Syeikh Abu Bakar wafat pada tahun 1933 M di Bintuhan, kondisi makam tersebut terpisah dari kedua makam di atas dan tidak dikeramik, hanya dibentuk dengan semen yang di cat berwarna hitam. Selain itu ukuran makam ini lebih panjang dari kedua makam tersebut. ${ }^{22}$ Semua batu nisan makam memakai keramik berwarna hitam dan jiratnya menghadap ke arah Timur. Namun, di baris pertama tertulis kalimat "innaalillahi wa innaailaihirooji'uun" dan hiasan seperti bunga yang mengelilingi pada tiap-tiap batu nisan tersebut. Perbedaan selanjutnya, pada makam Sayid Ahmad bin Ali bin Syeikh Abu Bakar dengan istrinya terdapat nisan lain berbentuk kubah masjid/ujung pedang di belakang nisan keramik tersebut. sedangkan pada makam Sayid Abdullah bin Ahmad bin Syeikh Abu Bakar tidak ada.

Adapun kondisi dari pada cungkup ini beratapkan genteng dari tanah merah, yang ditopang/disanggah oleh empat buah tiang beton berwarna putih, berada 
pada ke empat sisi serta dua buah tiang penyanggah dari kayu yang terletak di antara dua buah tiang beton, menghadap ke arah Selatan dan Utara. Kondisi dalam makam terlihat masih utuh dengan berlantaikan keramik yang bervariasi warna dan ukuran dan berdinding tembok berwarna putih sebagai pembatas untuk makam tersebut.

b) Makam Puyang Pinang Tawar

Selain makam Keluarga Sayid Ahmad bin Ali bin Syeikh Abu Bakar di atas, terdapat pula makam Puyang Pinang Tawar yang dianggap oleh masyarakat setempat sebagai makam keramat dan diakui keberadaannya. Posisi makam berada dekat dengan bibir pantai Bintuhan. Ketika peneliti melakukan observasi ke lokasi makam, di sekitar makam dikelilingi oleh rimbunan pohon dan dedaunan yang berada di perkebunan kelapa masyarakat desa Pengubaian tersebut. Makam yang diberi tanda dengan menggunakan jirat berukuran empat persegi panjang ini, dibentuk dengan menggunakan keramik kasar berwarna biru. Posisi makam menghadap ke arah pantai sebelah Barat dengan ukuran makam sekitar 1 meter lebih. Kondisi makam terlihat sama seperti pada makamKeluarga Habib Ahmad bin Ali bin Syeikh Abu Bakar yang bercungkup memilikidinding tembok dari semen sebagai pagar/pembatas. Namun, untuk atap memakai asbes bukan genteng. Selain itu keadaan makam terlihat tidak terawat dengan baik. Mungkin karena agak jauh dari perkampungan masyarakat sekitar, sehingga makam tersebut tidak terlalu diperhatikan dengan baik oleh masyakarat maupun pemerintahan daerah setempat.

Selanjutnya, apabila dikaji dari segi ceritanya tentang Makam Puyang Pinang Tawar ini, ternyata dari awal abad ke-20 $M$ sudah sangat terkenal. Hal ini berdasarkan pengakuan dari informan Saparudin berikut:

"Zaman bile ni waktu aku agi 'enik, lah terkenal benu'. Aw bile ni mu'jizatnye kuat benu' batu bile ni. Ulih ape kate u'ang Pinang Tawa', aya' semase di batang pinang tengah laut tu de masin. Ngan bukti-buktinye waktu kite kesitu, wui duku-duku ni masak-masak benu'. Makanlah waktu itu, aw uluhi agi waktu itu dak agi e, hanye waktu nungge tulah, hane be'angkat bawelah." 23

"Zaman dulu waktu aku masih kecil, sudah sangat terkenal. Karena dulu mu'jizat (keramat) nya sangat kuat sekali. Itulah kenapa orang menyebutnya Pinang Tawar, air yang didekat batang pinang yang berada di tengah lautan itu tidak asin. Sedangkan bukti-bukti lain waktu kita kesana, buah duku yang ada disana terlihat sangat matang. Makanlah waktu kita disana, ketika kita ingin kesana lagi, tidak ada lagi, hanya waktu kita bertemu saja, makanya ketika ingin berangkat bawalah."

Menurut informan dari Suardi Bakri penduduk desa Gedung Sako, Kecamatan Kaur Selatan menjelaskan bahwa Puyang Pinang Tawar adalah saudara dari Pangeran Cungkai di desa Parda Suka, Kecamatan Maje. ${ }^{24}$ Sementara menurut informan M. Napis Selamat mengatakan bahwa:

"Makam Pinang Tawar itu sebena'nye hanye tempat singgahnye saje seorang syeikh yang namenye Syeikh Abdullah. Pas nye ndak berangkat agi, nah 'upenye ditinggalkannyelah selindangnye disitu. 'Upe e ulih awak sini lokasi tempat nye ninggalkan selindang itu, dianggap ke'amat dan dibuatlah makamnye disitu."25

"Makam Pinang Tawar itu sebenarnya adalah tempat persinggahan seorang syeikh yang bernama Syeikh Abdullah. Namun, ketika ia ingin berangkat, rupanya ditinggalkanlah selendang/sal dibadannya disana. Rupanya oleh kita masyarakat sini lokasi tempat ditinggalkannya selendang itu, dianggap sebagai tempat keramat dengan dibangun sebuah makamnya disana."

c) Masjid Jamik Asy Syakiriin

Masjid Jamik Asy Syakiriin merupakan masjid yang tertua di Kota 
Bintuhan Kecamatan Kaur Selatan, Kabupaten Kaur. Secara administratif masjid ini berada di desa Air Dingin, tetapi secara umum masyarakat mengatakan bahwa masjidnya terletak di Bintuhan. Adapun kepastian tentang tahun berdirinya masjid Jamik ini belum dapat ditentukan baik oleh para tetua masyarakat setempat maupun oleh para pengurus masjid itu sendiri. Sebagian pendapat menyebutkan bahwa masjid ini sudah berdiri saat seorang musafir Arab, Sayid Ahmad bin Ali bin Syeikh Abu Bakar datang ke Bintuhan, yakni sekitar tahun 1820-an. ${ }^{26}$ Bahkan berdasarkan informan dari Nuzuar Zahari Said menjelaskan bahwa:

"Bile ni masjid Jamik ini masih 'enik benu', bedi'inye disebelah sini. Keki'e ukuran sekita' $8 x 8$ meter. Namun, ketika ndak dibesaki, tanahnye juge lah ade dibeli, barulah masjid sebelah ni pai ni digi'akkan dan dibangun baru yang bentuknye sama seperti bentuk masjid yang lame. Jelahlah masjid Jamik kite yang kini ni."27

"Dahulu masjid Jamik ini masih sangat kecil ukurannya, berdiri disebelah sini (maksudnya disamping kanan masjid Jamik yang sekarang ini). Kira-kira ukuran sekitar 8x8 meter. Namun, ketika hendak diperbesar, kemudian tanah tempat masjid ini ingin diperbesar sudah dibeli, barulah masjid ini (maksudnya masjid Jamik yang masih berukuran kecil) dirobohkan dan membangun yang baru masjidnya seperti bentuk masjid yang lama. Seperti yang terlihat masjid Jamik kita yang sekarang ini."

Adapun letak dari pada lokasi masjid ini apabila kita dari arah Utara Kota Bengkulu, berada di sebelah kanan jalan Raya Lintas Selatan. Posisi masjid menghadap ke jalan raya, yakni ke arah Timur. Untuk menuju lokasi masjid Jamik Asy Syakiriin ini, dapat ditempuh dengan berjalan kaki atau menggunakan kendaraan beroda dua dan empat. Apabila kita sudah berada di lapangan
Merdeka Bintuhan/di depan Masjid Agung Al-Kahfi Kaur, jaraknya ada sekitar 50 meter lagi ke arah Selatan. Ketika sudah berada di depan masjid Jamik ini, terlihat dari luar ada pagar tembok berwarna putih yang dikompilasi dengan trali besi berwarna hijau, termasuk juga pintu pagarnya. Ketika memasuki halaman masjid, ada sebuah gapura yang didominasi oleh warna hijau bertuliskan "Masjid Jamik Asy Syakiriin Bintuhan" berada diantara kedua tiangnya untuk menyambut kedatangan kita disana. Sebelah kiri bagian depan masjid ada sebuah beduk, tempat parkiran roda dua dan sebuah menara dengan empat susun yang telah dikeramik berwarna putih dan sedikit warna abu-abu. Sementara disebelah kanan bagian depan masjid ada sebuah bangun/kamar dengan dua pintu yang digunakan sebagai tempat penjaga masjidnya dan tempat mengaji anak-anak (TPQ).

Masjid Jamik yang berukuran 30×30 meter di bangun dengan konstruksi kayu berdinding tembok yang telah dikeramiki serta atapnya yang berwarna hijau berbentuk tumpang tiga susun dihiasi dengan kubah kecil berwarna emas di atasnya sebagaimana bentuk atap masjidmajid yang ada di Indonesia pada umumnya. Masjid ini terdiri dari enam pintu masuk yang masing-masing setiap dua pintu terletak disebelah Timur, Selatan dan Barat. Pada dua pintu sebelah Timur di cat berwarna hijau, sementara dua pintu disebelah Selatan dan Barat di cat berwarna putih bergaris hijau. Selain memiliki enam pintu, terdapat juga 32 buah daun jendela kaca yang semuanya berwarna hijau dengan tiangnya berwarna putih. Dari ke-32 buah daun jendela kaca tersebut berada pada ke empat arah, yakni masing-masing 12 buah jendela menghadap ke arah Utara dan Barat, sementara di sebelah Selatan ada 6 buah jendela dan di sebelah Timur ada 2 buah. Masjid ini hanya memiliki sebuah ruangan utama yang ditopang oleh empat tiang 
semen berukuran sedang yang telah dilapisi dengan keramik.

Masjid Jamik yang didominasi oleh warna hijau pada bagian luar ini memiliki teras masjid yang kira-kira berukuran 2 meter. Jarak antara teras dengan pagar tembok kira-kira sekitar 5 meter. Pada bagian dalam masjid terdapat 4 buah tiang persegi empat yang telah dikeramik berwarna orange berada ditengahtengahnya sebagai tiang penyangga plafon. Pada dinding dalam masjid bagian atas sebelah depan terdapat tulisan kaligrafi dengan menggunakan khat Tsulus bertinta hitam. Sedangkan pada bagian dalam dinding masjid disebelah kanan dan kirinya terdapat tulisan kaligrafi yang menggunakan khat Naskhi warna putih dengan background-nya berwarna hitam dan garis berwarna hijau sebagai bingkainya.

Adapun bentuk mimbar masjid menyerupai tangga seperti singgasana seorang raja yang berjumlah tiga tingkat dengan kombinasi warna hijau dan emas terbuat dari bahan semen tanpa keramik. Jika diperhatikan mimbar tersebut dipengaruhi oleh bentuk mimbar Timur Tengah yang telah dikreasi dengan budaya Nusantara. Antara mihrab dan mimbar tersebut ada dinding pembatas (terbagi menjadi dua ruangan) yang dikeramik berwarna hijau dengan masingmasing ruangan berukuran lebih kurang 1 meter berbentuk lorong setengah lingkaran. Sedangkan dinding yang terdapat pada mihrab dan mimbar semuanya di cat berwarna putih. Kecuali garis yang terdapat pada bentuk lorong setengah lingkaran tersebut. Pada mihrab, garis yang berbentuk setengah lingkaran tersebut di cat berwarna biru. Sementara pada mimbarnya di cat berwarna emas. Selain itu pada bagiansamping kiri mihrab ada seperti pintu dan bagian samping kanan mimbar terdapat seperti jendela yang dipasang trali besi. Kemudian pada bagian tengah antara mihrab dan mimbar (dinding pembatas) itu ada lobang berbentuk seperti tempat jendela yang diatasnya membentuk setengah lingkaran berwarna emas digunakan sebagai tempat menaroh alat pengeras suara masjid. Pada bagian depan mihrab dan mimbar terdapat 3 buah lobang berbentuk lingkaran sempurna dan 3 buah lingkaran berbentuk lonjong berguna sebagai ventilasinya.

d) Masjid Tua Bandar

Masjid Tua Bandar ini berdiri di tengah-tengah masyakarat Kelurahan Bandar, Kecamatan Kaur Selatan. Untuk mengunjungi lokasi masjid ini dapat ditempuh dengan berjalan kaki, menggunakan kendaraan beroda dua atau empat yang berjarak lebih kurang 100 meter. Ketika berada di Masjid Agung AlKahfi Kaur/Lapangan Merdeka Bintuhan, berjalan lurus melewati persimpangan 4 jalur melalui kantor Pos kelurahan Bandar ke arah Barat.

Berdasarkan hasil observasi, peneliti melihat bahwa ada beberapa bangunan masjid ini sudah rusak seperti pagar temboknya dan jendela. Terlihat bahwa kondisi dari pagar temboknya yang sudah tidak berbentuk lagi. Sedangkan kondisi dari pada jendela sebelah kanan masjid (arah Timur) yang satu sudah rusak 2 buah kacanya dan jendela yang satunya masih utuh. Kemudian untuk jendela sebelah kiri masjid (arah Barat) keduaduanya masih terlihat utuh. Masjid Tua Bandar ini dibangun dengan konstruksi kayu berdinding tembok berwarna putih dengan luas lebih kurang 8x5 meter serta beratapkan genteng dari tanahmerah pada bagian susun yang pertama dan beratapkan seng variasi berwarna hijau pada bagian susun kedua, sehingga berbentuk tumpang dua susun yang dilengkapi kubah kecil berwarna silver diatasnya. Pada bagian beranda masjid ada empat buah tiang bergaya tuscan yang masing-masing berukuran lebih kurang 1,5 meter dari permukaan tanah sebagai penyanggahnya. 
Ketika memasuki masjid tersebut terlihat ada dua pintu masuk utama berukuran lebih kurang 1,5 meter menghadap ke arah Selatan dengan 4 buah jendela kaca berbingkai kayu berbentuk persegi empat yang terletak pada bagian samping kanan dan kiri masjid masing-masing terdiri dari dua buah jendela menghadap kearah Timur dan Barat. Lantainya sudah berkeramik berwarna putih baik dibagian luar maupun dalam masjid, begitu juga dindingnya berwarna putih baik bagian luar maupun dalamnya. Sedangkan dinding Mihrab imam pada bagian depan berwarna hijau dan berwarna putih pada bagiansamping kanan kirinya. Adapun bentuk mihrab masjid ini sama seperti bentuk mihrabnya Masjid Jamik Asy Syakiriin Bintuhan. Bentuk Mimbar menyerupai tangga berjumlah tiga tingkat berwarna hijau terbuat dari semen dan pada bagian sampingnya berwarna kuning. Antara mihrab dan mimbar tersebut ada dinding pembatasnya (terbagi menjadi dua ruangan) yang masing-masing ukurannya lebih kurang $1 x^{1 / 2}$ meter berbentuk lorong setengah lingkaran.

Pada bagian dalam masjid ada sebuah tiang semen berwarna putih berbentuk persegi panjang yang lebarnya kira-kira $25 \mathrm{~cm}$. Selain itu, ada sebuah lemari kayu berwarna coklat kemerahan berukuran 1x1 meter yang berada dekat dengan pintu masuk sebelah kiri yang digunakan sebagai tempat untuk meletakkan al-Qur'an, buku Iqro', buku Yasiinan, dan lain-lain. Sementara sebelah kiri dekat mihrab ada sebuah papan tulis dan bangku yang digunakan untuk peralatan mengaji anak-anak.

Berdasarkan data dari informan $\mathrm{M}$. Shabri Abd Latief menyebutkan bahwa:

"Man aku de salah tahun 18-an, ade yang 32 pe'aseku. Mpuk masjid Jamik maupun masjid Bandar tu. Aw masjid Bandar jelah dipingkulan tu, kalu masjid Jamik lah 'ubuh yang lame itu pai ni na. Ka'ne bangun yang baru ni, mau tak mau itu di'ubuhkan." 28

"Kalau aku tidak salah tahun 18-an, ada yang mengatakan 32 (maksudnya tahun 1832) perasaanku. Baik masjid Jamik maupun masjid Bandar. Masjid Bandar terletak dipersimpangan itu, kalau masjid Jamik sudah roboh yang lama dahulu itu. Karena membangun yang baru ini, mau tak mau itu dirobohkan."

Pada waktu itu sebelum H. Fikir menjabat sebagai kepala pemerintah daerah, masjid ini sudah berdiri dan belum memiliki nama. Akan tetapi, pada masa H. Fikir memegang kepala pemerintahan setempat maka masjid tersebut di perbaiki dan diberi nama dengan sebutan Masjid Fikir Daud sebagai orang yang pertama merenovasinya.

e) Dokumentasi Pondok Pesantren Mu'awatul Her School (MHS)

Pondok pesantren ini apabila kita ingin membuktikan kebenarannya secara nyata untuk sekarang memang tidak dapat dibuktikan karena secara fisik bangunannya sudah tidak ada lagi. Berikut ini hasil penuturan dari informan Saparudin menyebutkan bahwa:

"Sekol MHS yang 'umahnye ditunggu anak Zaha'i Pasa' Lame hadapan Kopa, kan betingkat 'umah tu, na disitu 'umah MHS, damping dengan 'umah Sayid Ahmad." 29

"Sekolah MHS dulu rumahnya yang ditempati oleh anak bapak Zahari desa Pasar Lama didepan rumahnya bapak Kopa, rumah tersebut bertingkat, disanalah rumah tempat sekolah MHS dahulu, dekat dengan rumahnya Sayid Ahmad."

Dahulu lokasi sekolah itu dimiliki oleh seorang Khatib masjid Jamik Asy Syakiriin yang bernama Khatib Ma'ruf. Setelah sekolah MHS (Mu'awanatul Her School) itu pindah menjadi sekolah Nahdlatul Ulama (NU) di simpang 3 desa Pasar Lama, maka kemudian tempat tersebut menjadi Toko Gudang Garam. Terakhir lokasi itu menjadi milik bapak $\mathrm{H}$. 
Zahari Said (almarhum) ketika ia sudah membeli tanahnya. Sedangkan dokumentasi tersebut peneliti dapatkan dari anaknya bapak H. Zahari Said (almarhum) itu, yakni bapak H. Nuzuar Zahari Said. ${ }^{30}$

Selama tinggal di desa Air Dingin dengan maksud untuk berdagang, Sayid Ahmadbin Ali bin Syeikh Abu Bakarternyata mendirikan sebuah pondok pesantren sebagai tempat untuk belajar dan mendalami agama Islam yang dikenal dengan nama MHS (Mu'awanatul Her School) yang letak lokasinya berada dekat (dirumah) Tuan Sayid Ahmad bin Ali bin Syeikh Abu Bakar itu sendiri. ${ }^{31 B e l i a u}$ dibantu oleh beberapa tenaga pengajar dari luar daerah Bintuhan ${ }^{32}$ seperti Guru Ismail yang berasal dari Kalianda, Lampung.Pernyataan ini disampaikan oleh informan Saparudin ketika ditanya mengenai guru yang mengajar di MHS (Mu'awanatul Her School) tersebut. Berikut penuturan dari informan yang bersangkutan:

"Aman gu'u-gu'u itu, nyelah gu'u MHS/sekol MHS, pai NU ni pai nimbul biye, aman pai ni MHS. Gu'unye u'ang Kaliandak, Ismail u'ang Kaliandak.."33

"Kalau guru-guru itu, ialah guru MHS/sekolah MHS, bahwa dulu sebelum NU lahir adalah MHS yang terlebih dahulu ada. Gurunya ialah orang Kalianda, Ismail orang Kalianda..."

Menurut informan dari Arpan Efendi menyebutkan bahwa berdirinya Pondok Pesantren MHS (Mu'awanatul Her School) yakni di desa Gedung Sako yang dipelopori langsung oleh Ahmad Sayid bin Ali bin Syeikh Abu Bakar. ${ }^{34}$ Pondok pesantren itu kemudian dikembangkan oleh anaknya, yaitu Habib Alwi. Alasannya karena Gedung Sako itu menunjukkan 'Kota Santri', sebab di sana ada gedung yang 'Sako' atau tua yaitu gedung MHS (Mu'awatul Her School).

Selanjutnya pada waktu Sayid Ahmad bin Ali bin Syeikh Abu Bakar wafat, akhirnya pondok pesantren tersebut diwariskan kepada anaknya yang bernama Sarifah. Namun beberapa lama kemudian Sarifah pindah ke Kota Palembang.Sedangkan pondok pesantren itu diserahkan kepada masyarakat setempat untuk mengurusnya.Salah satu guru yang pernah mengajar disana ialah almarhum H. Supi Mukmin desa Jembatan Dua. ${ }^{35}$

f) Sekolah Nahdlatul Ulama (NU)

Sekolah Nahdlatul Ulama (NU) yang ada di Bintuhan ini merupakan sekolah lanjutan yang menggantikan sekolah MHS (Mu'awanatul Her School) di dekat rumahnya Sayid Ahmad bin Ali bin Syeikh Abu Bakar dahulu. Sekolah NU ini berdiri sekitar tahun 1920-an yang berdekatan dengan jalur pelabuhan Muara Bom desa Pasar Lama. Pernyataan tersebut sebagaimana yang disampaikan oleh informan Saparudin berikut ini:

"Sekol NU itu bedi'i pe'aseanku semenjak aku ingat itu lah ade. Gu'u-gu'unye yelah "umbungan Sayid Ahmad tian itu." "Sekolah NU itu berdiri perasaanku semenjak aku ingat/lahir dia sudah ada. Guru-guru yang mengajarnya ialah rombongan Sayid Ahmad itu." 36

Berdasarkan hasil wawancara dengan informan M. Shabri Abd Latief menjelaskan bahwa:

"Masuknye kesini ini, sebelum merdeka. Bahkan pengetahuanku man de salah waktu aku sekol PGA pai ni, di SMEA ni bak kini, aa itu mijah pai ni kan be'angkai, na mi'it buatnye itu tahun due puluh satu (tahun 1921)." 37

"Masuknya Islam kesini ini, sebelum merdeka.Bahkan ketika aku bersekolah PGA dulu, yang sekarang menjadi SMEA (SMK), pada meja yang tersusun itu tertuliskan angka tahun 1921."

Berdasarkan hasil observasi dilapangan, peneliti tidak menemukan bentuk bangunan lama sekolah tersebut. Akan tetapi, hanya terlihat bentuk bangunan yang baru. ${ }^{38}$ Kemudian informasi mengenai sejarah lengkap tentang sekolah ini tidak terlalu 
mendalam data yang peneliti dapatkan, karena mengingat bahwa dari sekian banyak informan yang peneliti wawancarai tidak mengetahui akan keberadaan sekolah tersebut.

Selanjutnya jika di pikir-pikir mengapa sekolah tersebut tidak dipertahankan sampai sekarang? kemungkinan besar akibat dari tekanan penjajah yang berada di Kota Bintuhan sesudah dua tahun dari kemerdekaan RI. Seperti yang di ketahui bahwa dua tahun pasca kemerdekaan RI, Jepang kembali menjajah Indonesia akibat ketidaksetujuaannya terhadap kemerdekaan RI tersebut. dalam proses penjajahan inilah salah satu kebijakan dari Pemerintahan Jepang yakni membatasi tingkat pendidikan di Indonesia. Hal itupun merambat di Kota Bintuhan. Akibat dari kebijakan Pemerintahan Jepang inilah sehingga Sekolah Nahdlatul Ulama (NU) tidak dapat bertahan sampai sekarang. bahkan tingkat pendidikan yang dibolehkan oleh Pemerintahan Jepang pada saat itu hanya sebatas kelas dua HIS ${ }^{39}$. Pernyataan ini sesuai dengan yang disampikan oleh informan M. Shabri Abd Latief berikut:

"Sekol di awak Bintuhan mpai ni jelah itulah ade yang bebentuk pesantren pengajian ade bentuk pendidikan nihan. Aw waktu itu de bulih tinggi sekolle, hanye batas kelas due saje. Tapi walaupun kelas due HIS waktu itu, ngalahkan SMA kini." 40

"Sekolah kita di Bintuhan dulu ialah ada yang berbentuk pesantren pengajian dan ada juga yang benar-benar berbentuk pendidikan. Pada waktu itu sekolahnya tidak boleh tinggi, hanya batas kelas dua saja. Tapi pada waktu itu walaupun hanya kelas dua HIS, tingkatannya sama dengan SMA sekarang."

g) Buku lama/kitab Sayid Ahmad

Adapun yang dimaksud dengan buku lama/kitab Sayid Ahmad yaitu buku cetak yang berjudul tentang Penjelasan berbagai ilmu dalam al-Qur'an yang ditulis oleh 'Abdul Aziz Hayi dan
Ahmi Muhammad pada tahun 1924 H/1342 M di Darul Ahya', Mesir. Buku yang bertuliskan Arab dengan kertas berwarna kuning ini terdapat sebuah gambar stempel bertuliskan "Sayid Ahmad bin Abu Bakar bin Bemar bin Jahur" dibagian belakang sampulnya. Sehingga diduga bahwa buku lama tersebut merupakan milik dari Sayid Ahmad bin Ali bin Syeikh Abu Bakar ketika beliau menjadi tenaga pengajar di Pondok Pesantren/Sekolah MHS (Mu'awanatul Her School) di Kota Bintuhan.

Berdasarkan hasil wawancara dengan informan Arpan Efendi melalui via telepon, disebutkan bahwa ada 95 halaman dan 37 pasal pembahasan di dalam buku ini yang menjelaskan isi bukunya. Beberapa diantara pasal-pasal yang disebutkan dalam buku ini yaitu tentang iman dan amal manusia, tentang keadaan langit dan bumi secara umum, tentang sifat-sifat dan perbedaan gerak pada hewan, tentang tumbuh-tumbuhan, tentang ilmu falak/perbintangan, tentang beberapa tafsiran ayat dalam al-Qur'an salah satu contohnya ayat dalam surat AnNahl serta masih banyak pasal yang dibahas dalam buku ini. Buku lama/kitab itu di simpan rapi oleh bapak Arpan Efendi desa Pasar Sauh. ${ }^{41}$

Selanjutnya, dalam kegiatan observasi terhadap buku tersebut didapatkan hasil yang menunjukkan bahwa kondisi secara keseluruhan dari pada bukunya ini masih utuh dan isinya juga masih dapat dibaca walaupun secara fisik ada beberapa lembar halaman yang sudah terlepas lemnya. Buku/kitab Sayid Ahmad ini memiliki ketebalan $0,5 \mathrm{~cm}$ dengan ukuran $19,5 \times 13,5 \mathrm{~cm}$. Tulisan pada bagian covernya terdapat iluminasi ${ }^{42}$ yang mengelilinginya

\section{Sejarah Masuknya Islam di Kota Bintuhan Kecamatan Kaur Selatan Kabupaten Kaur}

Sebagaimana pendapat yang dikemukakan oleh Ricklefs dalam 
bukunya yang berjudul Sejarah Indonesia Modern menyebutkan bahwa ada dua kemungkinan proses penyebaran agama Islam di Indonesia. Pertama, penduduk pribumi berhubungan dengan agama Islam dan kemudian menganutnya. Kedua, orang-orang asing Asia (Arab, India, Cina, dll.) yang telah memeluk agama Islam bertempat tinggal secara permanen di suatu wilayah Indonesia, melakukan perkawinan campuran dan mengikuti gaya hidup lokal sampai sedemikian rupa, sehingga mereka sudah menjadi orang Jawa atau Melayu ataupun sudah termasuk dalam anggota suku-suku tertentu. ${ }^{43}$ Sepertinya pendapat yang dikemukakan diatas dapat menjadi bukti bahwa sejarah masuknya Islam di Kota Bintuhan memang benar berasal dari orang asing, yakni orang Arab yang bernama Sayid Ahmad bin Ali bin Syeikh Abu Bakar yang telah memeluk agama Islam, bertempat tinggal secara permanen di Bintuhan khususnya di Kampung Masjid desa Air Dingin Kecamatan Kaur Selatan dan kemudian melakukan perkawinan dengan wanita pribumi yang bernama, Aliyah.

Berdasarkan

dari teori

Arab/Makkah menyebutkan bahwa para pedagang Arab terlibat aktif dalam penyebaran Islam di Nusantara ini, salah satunya di Kota Bintuhan. Berbagai ahli telah mengemukakan pendapatnya tentang asal-usul Islam di Nusantara ini. Diantaranya, Crawfurd mengatakan bahwa Islam dikenalkan pada masyarakat di Nusantara langsung dari Tanah Arab. Keyzer berpendapat bahwa Islam di negeri ini berasal dari Mesir. Kemudian Niemann dan de Hollander, dengan sedikit versi mengatakan bahwa Islam di Indonesia berasal dari Hadramaut.Sementara P. J. Veth berpandangan bahwa orang-orang Arab yang melakukan kawin campur dengan penduduk pribumi yang berperan dalam penyebaran Islam di permukiman baru mereka di Nusantara. ${ }^{44}$
Mengutip dari pendapatnya Niemann dan de Hollander yang mengatakan bahwa Islam di Indonesia berasal dari Hadramaut, salah satunya di Bintuhan. Sayid Ahmad bin Ali bin Syeikh Abu Bakar merupakan seorang musafir yang berasal dari Hadramaut, Yaman sewaktu tiba di Bintuhan langsung melakukan perdagangan. Pada waktu berdagang, Sayid Ahmad bin Ali bin Syeikh Abu Bakar ini juga aktif berdakwah dalam rangka mengenalkan Islam kepada masyarakat Kota Bintuhan. Dari sinilah masyarakat mulai memahami ajaran-ajaran agama yang mereka anut. Masyarakat Bintuhan meyakini bahwa ajaran/faham yang diajarkan oleh Sayid Ahmad terhadap pemahaman agama ini disebut Ahlussunnah wal Jamaahatau yang lebih dikenal dengan ajaran Nahdlatul Ulama (NU). Walaupun sebenarnya agama Islam di Kota Bintuhan ini sudah ada lebih awal jika dibandingkan dengan kedatangan Sayid Ahmad bin Ali bin Syeikh Abu Bakar tersebut. Adapun proses Islamisasi yang dilakukan oleh Sayid Ahmad bin Syeikh Abu Bakar terhadap Kota Bintuhan, yakni dengan melalui jalur perdagangan, perkawinan dan pendidikan.

a) Jalur Perdagangan

Berdasarkan uraian diatas menyebutkan bahwa kedatangan Sayid Ahmad bin Ali bin Syeikh Abu Bakar ke Bintuhan adalah untuk berdagang. Namun, sudah menjadi kebiasaan orang Arab apabila mereka melakukan perdagangan di suatu daerah maka akan diiringi dengan mendakwahkan agama Islam. Akan tetapi memang sudah sepantasnya apabila seorang Muslim mendakwahkan Islam kepada pihak yang lain. Alasannya karena hal tersebut merupakan suatu kewajiban yang harus dilaksanakan, disamping itu pula dalam Islam tidak ada pemisahan antara aktivitas perdagangan dengan kewajiban mendakwahkan Islam.

b) Jalur Perkawinan 
Dalam tahap berikutnya Sayid Ahmad bin Ali bin Syeikh Abu Bakar melakukan perkawinan dengan orang pribumi dengan tujuan agar terjadi hubungan yang akrab dan baik, sehingga memungkinkan terjadinya perkawinan campur dan mengikuti kebiasaan orang pribumi. Sayid Ahmad bin Ali bin Syeikh Abu Bakar mengawini wanita pribumi bernama Aliyah agar memiliki peranan penting dalam proses internalisasi ajaran Islam di Kota Bintuhan, baik dalam arti pengislaman maupun pemasukan nilainilai dan norma-norma Islam ke dalam lingkungan masyarakat. Kemudian dari perkawinan tersebut keturunannya juga ikut melakukan kawin campur dengan orang pribumi, seperti Habib Alwi yang mengawini wanita Bintuhan bernama Zaina/Zaidah.

c) Jalur Pendidikan

$$
\text { Proses Islamisasi melalui }
$$
pendidikan seperti yang terjadi di Indonesia pada umumnya yakni dengan mendirikan lembaga pendidikan Islam yang disebut pesantren. Cara ini juga dilakukan Sayid Ahmad bin Ali bin Syeikh Abu Bakar ketika melakukan Islamisasi di Bintuhan. Terbukti bahwa sejak kedatangannya ke Bintuhan, Pondok Pesantren yang diberi nama MHS (Mu'awatul Her School) ini sangat berpengaruh terhadap masyarakat setempat. Kontribusinya terlihat ketika lulusan dari pesantren ini dikirim ke negara Arab dan Mesir untuk melanjutkan pendidikan Islam yang lebih mendalam. Sedangkan salah satu tenaga pengajarnya yang diketahui selain Sayid Ahmad bin Ali bin Syeikh Abu Bakar sendiri ialah guru Ismail sebagaimana informasi yang di dapat dari informan Saparudin (92 tahun) dalam uraian diatas.

\section{Jejak-Jejak Peninggalan Islam di Kota Bintuhan}

Pada umumnya bukti-bukti peninggalan Islam di Indonesia yakni dapat berupa makam dan bentuk nisannya, bangunan masjid, aliran mazhab yang digunakan masyarakatnya, adanya orang Arab yang bergelar sayyid atau syarif selaku keturunan dari Nabi Muhammad Saw yang datang ke Nusantara guna melanjutkan proses Islamisasi tersebut. Selanjutnya dilihat dari uraian tentang jejak-jejak peninggalan Islam di Kota Bintuhan diatas, membuktikan bahwa proses Islamisasi di Indonesia telah merambat hingga ke Kota Bintuhan. Berikut pembahasan mengenai jejak-jejak peninggalan Islam di Kota Bintuhan.

a) Makam Keluarga Habib Ahmad bin Ali bin Syeikh Abu Bakar

Makam ini menunjukkan makam Islam karena terlihat dari namanya yang memakai gelar sayyid didepannya. Jika ditinjau dari segi bentuknya makam ini lebih kepada bentuk makam modern yang sekarang. Berbeda dengan makam-makam yang ada di Indonesia pada saat menentukan asal-usul Islamnya. Hal ini seperti yang diamati oleh beberapa ahli sejarah terhadap makam ditemukan pada prasasti batu nisan seorang wanita bernama Fatimah binti Maimun di Leran Gresik yang berangka tahun $475 \mathrm{H}$ atau $1082 \mathrm{M}$ memiliki kesamaan dengan bentuk nisan yang ada di Cambay, Gujarat di pesisir India Selatan. ${ }^{45}$ Hal serupa juga dilakukan terhadap bentuk batu nisan di Pasai yang berangka 17 Dzulhijjah 831 H/27 September 1428. Selanjutnya bentuk nisan pada makan Maulana Malik Ibrahim di Gresik Jawa Timur juga ikuti menjadi objek pengamatan untuk menentukan Islam di Indonesia.

Sedangkan makam Keluarga Habib Ahmad bin Ali bin Syeikh Abu Bakar yang ada di Bintuhan hanya sebagai bukti bahwa Islam telah dibawa oleh seorang musafir dari Hadramaut, Yaman. Apabila dikaji dari segi tahunnya, Makam Sayid Ahmad bin Ali bin Syeikh Abu Bakar ini menunjukkan tahun wafatnya yang berangka $1943 \mathrm{M}$.

b) Makam Puyang Pinang Tawar 
Makam Puyang Pinang Tawar adalah sebuah makam Islam yang terletak di desa Pengubaian, Kecamatan Kaur Selatan berada pada tanah datar disekitar pantai Kaur lebih kurang 50 meter dengan ukuran $3 \times 4$ meter. Menurut informasi masyarakat bahwa dahulu lokasi sekitar makam ini pernah dijadikan sebagai tempat musyawarah bagi para raja di Kaur, diantaranya Raja/Pangeran Cungkai, Balin dan lain-lain.46 Sementara itu disisi lain makam ini dipercaya oleh masyarakat Kaur sebagai tempat persinggahan Puyang Pinang Tawar/Dayang Pandan, sehingga dikeramatkan. Tempat keramat tersebut ditandai dengan jirat makam berdenah empat persegi panjang yang dibangun dengan tembok dan ubin porselen. ${ }^{47}$

Menurut informan Suardi Bakri, penduduk desa Gedung Sako, Kecamatan Kaur Selatan menjelaskan bahwa Puyang Pinang Tawar adalah saudara dari Pangeran Cungkai di desa Parda Suka, Kecamatan Maje.48 Sementara menurut Selamat, makam Puyang Pinang Tawar di desa Pengubaian tersebut adalah tempat persinggahan seorang syeikh yang bernama Syeikh Abdullah. Namun, ketika ia ingin berangkat ditinggalkanlah selendang/sal dibadannya disana, sehingga masyarakat setempat meyakini lokasi sekitar persinggahan tersebut sebagai tempat keramat dengan dibangun sebuah makam. ${ }^{49}$ Kemudian menurut penjelasan dari informan M. Shabri Abd Latief menyebutkan bahwa makam Puyang Pinang Tawar di desa Pengubaian itu bukanlah makam yang sesungguhnya, melainkan hanya tempat persinggahan saja. ${ }^{50}$ Sedangkan Menurut Rahima Thaib, sebagai tempatnya berhenti untuk melaksanakan shalat.51 Adapun makam Puyang Pinang tawar yang sesungguhnya itu ialah makam seorang Aminullah yang berasal dari Padang, Sumatra Barat yang wafat di daerah Manunglah perbatasan dengan Krui. Sedangkan dalam bukunya Zulneli Zubir yang berjudul Peninggalan
Sejarah dan Potensi Wisata Kabupaten Kaur Propinsi Bengkulu menyebutkan bahwa menurut Juru Kunci makam ini, Suardi bin Thahar menjelaskan bahwa makam Puyang Pinang Tawar ini adalah makam Aminullah yang berasal dari Jawa sekitar abad ke-16 M datang ke Bintuhan. ${ }^{52}$

c) Masjid Jamik Asy Syakiriin dan Masjid Tua Bandar

Berdasarkan sejarah lokal, menyebutkan bahwa kedua masjid ini adalah masjid tertua yang berada di Bintuhan. Khusus masjid Jamik, berdasarkan informan yang disampaikan oleh Ratna Suri menyebutkan bahwa berdirinya masjid Jamik ini sezaman dengan masa ketika ibu dari informan masih muda dan pada waktu itu Sayid Ahmad bin Ali bin Syeikh Abu Bakar menjadi pembina masjid untuk para pemuda dan remajanya. ${ }^{53}$ Sedangkan informasi mengenai berdirinya masjid Tua Bandar ini yang terkenal di masyarakat sebagai pendirinya, yaitu H. Fikir Daud sekitar tahun 1920-an yang dibantu oleh seorang muslim dari Cinayang belakangan dikenal dengan nama $H$. Abdul Karim (Oei Ching Shein). ${ }^{54}$ Selanjutnya ketika H. Fikir Daud ini wafat, maka digantikan dengan cucunya yang bernama $\mathrm{H}$. Daud selaku imam masjid tersebut. Untuk sekarang masjid ini difungsikan sebagai sekolah agama dengan nama Madrasah Diniyah Awaliyah (MDA). 55

d) Dokumentasi Pondok Pesantren MHS (Mu'awatul Her School) dan Sekolah Nahdlatul Ulama (NU)

Pada tahun 1819 / 1820 M masyarakat Kaur (Bintuhan) sudah mengenal istilah 'pesantren' seperti sekarang ini. Berdirinya Pondok Pesantren MHS (Mu'awatul Her School) diperkirakan pada tahun $1832 \mathrm{M}$ (sekitar menjelang pertengahan abad ke-19 M). Sehingga diasumsi oleh informan M. Shabri Abd Latief bahwa Islam masuk ke Bintuhan berbarengan dengan tahun berdirinya Pondok Pesantren MHS (Mu'awatul Her 
School) tersebut.56 Adapun sistem pengajaran yang diterapkan dalam pondok pesantren ini adalah seperti yang terlihat pada organisasi Nahdlatul Ulama (NU) sekarang. Bahkan sekitar tahun 1920-an, di Bintuhan dulu ada sekolah yang berbasiskan Nahdlatul Ulama(NU) terletak di simpang 3 (tiga) desa Pasar Lama. Kemudian sekarang sekolah tersebut berganti nama menjadi Sekolah Menengah Kejuruan (SMK) Ma'arif Kaur. 57

Selanjutnya dari pesantren MHS (Mu'awanatul Her School) inilah melahirkan santri-santri yang dikirim ke tanah Arab dan Mesir. Diantaranya $\mathrm{H}$. Nurdin Kampung, H. Alwi Syukur, H. Muh. Nur, H. Idris. Diketahui bahwa $H$. Nurdin Kampung dan H. Alwi Syukur telah berpuluhan tahun belajar di tanah Arab. Sedangkan H. Idris telah belajar di Mesir puluhan tahun juga, sampai-sampai beliau menyelesaikan Strata 1 (S1) di Mesir, kemudian menjadi dosen disana. Setelah pulang dari Mesir, beliau menjadi dosen di Universitas Sriwijaya (UNSRI) Palembang. ${ }^{58}$ Pada akhirnya meninggal dunia di Kota Palembang, Sumatra Selatan. 59

e) Buku Lama/Kitab Sayid Ahmad bin Ali bin Syeikh Abu Bakar

Persoalan mengenai buku lama/kitab ini sebenarnya sudah dijelaskan pada uraian hasil penelitian di atas. Artinya secara umum tema yang di bahas dalam buku/kitab Sayid Ahmad bin Ali bin Syeikh Abu Bakar ini menjelaskan bahwa al-Qur'an merupakan sumber ilmu/petunjuk bagi segala aspek dalam kehidupan dimuka bumi, baik tentang ilmu manusia, hewan maupun tumbuh-tumbuhan. Di antara pembahasan isi buku ini menyebutkan bahwa dalam hal tauhid, kehidupan semua makhluk di muka bumi ini telah di atur oleh Allah Swt dan terkhusus bagi makhluk jin dan manusia di perintahkan untuk mengabdi/beribadah hanya kepada-Nya.
Sementara itu dalam hal muamalah, manusia disuruh untuk memperhatikan sifat yang di miliki oleh makhluk Allah yang bernama lebah sebagaimana yang tercantum dalam satu surat dalam alQur'an, yakni surat an-Nahl. Salah satu sifat baik yang di miliki lebah tersebut tidak mengganggu/merusak sesuatu yang di hinggapinya. Maka hendaknya manusia juga harus memiliki sifat tidak mengganggu orang lain/merusak bumi Allah Swt ini.

\section{Kesimpulan}

Berdasarkan hasil penelitian dan pembahasan tentang sejarah Islam di Kota Bintuhan Kecamatan Kaur Selatan Kabupaten Kaur di atas, maka dapat disimpulkan sebagai berikut:

1. Sejarah masuknya Islam di Kota Bintuhan Kecamatan Kaur Selatan Kabupaten Kaur dibawa oleh seorang Musafir Arab bernama Sayid Ahmad bin Ali bin Syeikh Abu Bakar pada pertengahan abad ke-19 M (sekitar tahun 1820-an) di desa Air Dingin tepatnya sekarang lebih dikenal dengan Kampung Masjid, tempat di mana Masjid Jamik Asy Syakiriin Bintuhan berdiri sekarang.

2. Adapun jejak-jejak peninggalan Islam di Kota Bintuhan yang menjadi bukti bahwa agama Islam telah masuk di daerah tersebut yakni berupa Makam Keluarga Habib Ahmad bin Ali bin Syeikh Abu Bakar terletak di desa Jembatan Dua, Makam Puyang Pinang Tawar di desa Pengubaian, Masjid Jamik Asy Syakiriin di Kampung Masjid desa Air Dingin, Masjid Tua Bandar di Kelurahan Bandar, Pondok Pesantren Mu'awatul Her School (MHS) yang didapat dari H. Nuzuar Zahari Said di desa Air Dingin (Kampung Masjid), Sekolah Nahdlatul Ulama (NU) di simpang 3 (tiga) desa Pasar Lama dan yang terakhir buku lama/kitab berbahasa Arab milik Sayid Ahmad bin Ali bin 
Syeikh Abu Bakar dengan judulnya, yakni penjelasan berbagai ilmu dalam al-Qur'an.

\section{Referensi}

1Zulneli Zubir, Peninggalan Sejarah dan Potensi Wisata Kabupaten Kaur Propinsi Bengkulu, (Padang: BPSNT Padang, 2011), Hal. 76

2Sidarmin Tetap, Tafsir Santri Terhadap Binakarakter Bumi Si Pahit Lidah Edisi 1 Tembe Jagad Lingge, (Bintuhan: Yaplat, 2012), Hal. 3031

${ }^{3}$ EIC (East India Company) sebutan untuk Kompeni Inggris

${ }^{4}$ Abdullah Siddik,Sejarah Bengkulu 15001990, Hal. 30

${ }^{5}$ William Marsden, Sejarah Sumatra, (Jakarta: Komunitas Bambu, 2013), Hal. 166

'Sarwit Sarwono, et al., Budaya Masyarakat Bengkulu: Tradisi Berladang, Kepimpinan dan Eksistensi Seni, (Padang: BPSNT Padang Press, 2012), Hal. 217. Lihat juga Zulneli Zubir, Peninggalan Sejarah dan Potensi Wisata Kabupaten Kaur Propinsi Bengkulu, Hal. 41

7Sarwit Sarwono, et al., Budaya Masyarakat Bengkulu: Tradisi Berladang, Kepimpinan dan Eksistensi Seni, Hal. 200

${ }^{8}$ Arpan Efendi, Wawancara, 29 Oktober 2015, Pukul 18 : 45 Wib

9Syeikh Muhammad Ali merupakan nama panggilan yang diketahui oleh orang Bintuhan (bukan nama aslinya).

10Syarkawi, Wawancara, Rabu 13 April

2016, Pukul 20 : 00 Wib

11Saparudin, Wawancara, Selasa 19 April 2016, Pukul 10 : 45 Wib

${ }^{12}$ Awalnya desa Air Dingin ini dulu merupakan bagian dari desa Pasar Lama, kemudian dikenal dengan nama Kampung Cina karena banyak para pedagang Cina dari Kota Palembang (Sumsel) mendirikan rumahnya sebagai komunitas di Kota Bintuhan, tapi sekarang berubah menjadi Kampung Masjid disebabkan karena penduduknya mayoritas Muslim/Islam.

${ }^{13}$ H. M. Arsyad, Wawancara, Selasa 19 April 2016, Pukul 08 : 30 Wib

${ }^{14} \mathrm{H}$. Warda, Wawancara, Selasa 19 April 2016, Pukul 19: 00 Wib
${ }^{15}$ Arpan Efendi, Wawancara, Jum'at 22 April 2016, Pukul 13 : 00 Wib

${ }^{16} \mathrm{H}$. M. Napis Selamat, Wawancara, Minggu 17 April 2016, Pukul 08 : 40 Wib

${ }^{17}$ Arpan Efendi, Wawancara, Jum'at 22 April 2016, Pukul 13 : 00 Wib

${ }^{18} \mathrm{Hj}$. Rohima Thaib, Wawancara, Jum'at 22 April 2016, Pukul 08 : 00 Wib

${ }^{19}$ Menurut Saparudin menyebutkan bahwa istrinya Habib Alwi adalah Zaidah

${ }^{20}$ Arpan Efendi, Wawancara, Jum' at 22 April 2016, Pukul 13 : 00 Wib

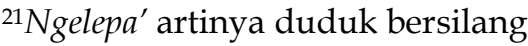
seperti duduk ketika lesehan atau dalam bahasa pesantrennya "Sarasehan".

${ }^{22}$ Tentang makam tersebut dapat dilihat dalam lampiran pada gambar 1

23Saparudin, Wawancara, Selasa 19 April 2016, Pukul $10: 45$ Wib

${ }^{24}$ H. Suardi Bakri, Wawancara, Sabtu 16 April 2016, Pukul 07 : 00 Wib

${ }^{25} \mathrm{H}$. M. Napis Selamat, Wawancara, Minggu 17 April 2016, Pukul 08 : 40 Wib. Tentang makam Puyang Pinang Tawar ini dapat dilihat dalam lampiran pada gambar 2

${ }^{26} \mathrm{M}$. Shabri Abd Latief, Wawancara, Kamis 21 April 2016, Pukul 16 : 00 Wib. Hj. Ratna Suri, Wawancara, Jum'at 22 April 2016, Pukul 08:00 Wib

${ }^{27} \mathrm{H}$. Nuzuar Zahari Said, Wawancara, Jum'at 22 April 2016, Pukul 13 : 30 Wib. Bentuk masjid jamik tersebut dapat dilihat dalam lampiran pada gambar 3

${ }^{28} \mathrm{M}$. Shabri Abd Latief, Wawancara, Kamis 21 April 2016, Pukul 16 : 00 Wib. Tentang masjid Tua Bandar ini dapat dilihat dalam lampiran pada gambar 4

29Saparudin, Wawancara, Selasa 19 April 2016, Pukul 10 : 45 Wib

30Tentang fotonya dapat dilihat dalam lampiran pada gambar 5

${ }^{31}$ H. Nuzuar Zahari Said, Wawancara, Jum'at 22 April 2016, Pukul 13 : 30 Wib. Tentang lokasi ini dapat dilihat dalam lampiran gambar 6

${ }^{32}$ Berdasarkan informasi dilapangan menyebutkan bahwa ada sekitar 5-7 orang guru/tenaga pengajar yang mengajar di Ponpes MHS, salah satu yang masih diketahui yaitu Guru Ismail tersebut.

33Saparudin, Wawancara, Selasa 19 April 2016, Pukul 10 : 45 Wib 
${ }^{34}$ Arpan Efendi, Wawancara, Jum'at 22 April 2016, Pukul 13 : 00 Wib. Tentang lokasi berdirinya Ponpes MHS di desa Gedung Sako dapat dilihat dalam lampiran pada gambar 7

${ }^{35} \mathrm{H}$. Suardi Bakri, Wawancara, Sabtu 16 April 2016, Pukul 07 : 00 Wib

36Saparudin, Wawancara, Selasa 19

April 2016, Pukul 10 : 45 Wib

${ }^{37} \mathrm{M}$. Shabri Abd Latief, Wawancara, Kamis 21 April 2016, Pukul 16 : 00 Wib

${ }^{38}$ Bentuk bangun sekolah tersebut dapat

dilihat dalam lampiran pada gambar 8 ${ }^{39} \mathrm{HIS}$ adalah sebutan nama sekolah

Belanda yang telah diambil alih oleh Jepang ${ }^{40} \mathrm{M}$. Shabri Abd Latief, Wawancara,

Kamis 21 April 2016, Pukul 16 : 00 Wib

${ }^{41}$ Arpan Efendi, Wawancara melalui via telepon, Jum'at 20 Juni 2016, Pukul 06 : 30 Wib. Tentang dokumentasi buku lama/kitab Sayid Ahmad ini dapat dilihat dalam lampiran pada gambar 9

${ }^{42}$ Iluminasi $=$ hiasan

${ }^{43}$ M. C. Ricklefs, Sejarah Indonesia Modern, terj. Dharmono Hardjowidjono, (Yogyakarta: Gadjah Mada University Press, 1994), Hal. 3

${ }^{44}$ Nor Huda, Islam Nusantara; Sejarah Sosial Intelektual Islam di Indonesia,(Jogjakarta: Ar-Ruzz Media, 2007), Hal. 36

${ }^{45}$ Nor Huda, Islam Nusantara; Sejarah Sosial Intelektual Islam di Indonesia, Hal. 33

46Zulneli Zubir, Peninggalan Sejarah dan

Potensi Wisata Kabupaten Kaur Propinsi Bengkulu, (Padang: BPSNT Padang, 2011), Hal. 75

${ }^{47}$ Ade Oka Hendrata, et al., Peradaban di Pantai Barat Sumatra: Perkembangan Hunian dan Budaya di Wilayah Bengkulu, (Yogyakarta: Penerbit Ombak, 2013), Hal. 50

${ }^{48} \mathrm{H}$. Suardi Bakri, Wawancara, Sabtu 16 April 2016, Pukul 07 : 00 Wib

${ }^{49} \mathrm{H}$. M. Napis Selamat, Wawancara, Minggu 17 April 2016, Pukul 08 : 40 Wib

${ }^{50} \mathrm{M}$. Shabri Abd Latief, Wawancara, Kamis 21 April 2016, Pukul 16:00 Wib

${ }^{51} \mathrm{Hj}$. Rohima Thaib, Wawancara, Jum'at 22 April 2016, Pukul 08 : 00 Wib

52Zulneli Zubir, Peninggalan Sejarah dan Potensi Wisata Kabupaten Kaur Propinsi Bengkulu, Hal. 76

${ }^{53} \mathrm{Hj}$. Ratna Suri, Wawancara, Jum'at 22 April 2016, Pukul 08 : 00 Wib
${ }^{54}$ Zulneli Zubir, Peninggalan Sejarah dan Potensi Wisata Kabupaten Kaur Propinsi Bengkulu, Hal. 78

${ }^{55}$ Ade Oka Hendrata, et al., Peradaban di Pantai Barat Sumatra: Perkembangan Hunian dan Budaya di Wilayah Bengkulu, Hal. 48

${ }^{56} \mathrm{M}$. Shabri Abd Latief, Wawancara, Kamis 21 April 2016, Pukul 16:00 Wib

57Saparudin, Wawancara, Selasa 19 April 2016, Pukul 10 : 45 Wib

${ }^{58}$ Arpan Efendi, Wawancara, Jum'at 22 April 2016, Pukul 13 : 00 Wib

${ }^{59} \mathrm{M}$. Shabri Abd Latief, Wawancara, Kamis 21 April 2016, Pukul 16 : 00 Wib 